\title{
Influence of alcohol consumption on risky behaviors among students of first and fourth year of the Medical Faculty
}

\begin{abstract}
Introduction. The problem university students' drinking in Poland has evoked greater interest lately. Numerous studies conducted in the recent years have indicated an increase in consumption of high-proof alcoholic beverages among students.

Aim. The aim of the study was to explore the influence of alcohol over on risky behavior among first and fourth year students of the Medical Faculty at the Medical University in Lublin during the academic year 2011/2012.

Material and methods. The study looked at 120 students, 45 men and 75 women; 60 people from the first and 60 people from the fourth year of the Medical Faculty. The method of an author's original questionnaire, which was fully anonymous, was used. Answering 22 questions included in the questionnaire was voluntary, those completing the questionnaires could refuse to participate in the study at any time.

Results. Statistically significant correlations between students who abused alcohol and their risky behaviors were found.

Conclusions. There are some negative consequences of young people's drinking alcohol and the most frequent symptoms They include: driving under the influence, engaging in risky sexual behaviors or starting fights. Several respondents admitted that they were passengers while the driver was intoxicated. Students being in a state of intoxication more often engaged in sexual activities. Alcohol consumption might also result in irrational decisions which could endanger health and lives e.g.: jumping from a roof. A few students of the fourth year were occasionally involved in gambling. A number of students admitted undergoing medical assistance after alcohol consumption.
\end{abstract}

Keywords: alcohol, harmful drinking, risky drinking.

DOI: $10.1515 /$ pjph-2015-0052

\section{INTRODUCTION}

A group of people, particularly students, drinking in a risky and harmful way is the subject of a special interest for health and social policies [1]. Risky alcohol consumption means drinking excessive amounts of alcohol (at one time and in a given time interval) not involving negative health consequences at present, although it may be expected that these consequences will appear if the present model of alcohol consumption is not changed. This model of drinking includes risky behavior such as: injuries resulting from accidents, assault and battery, suicides or casual sexual contacts. Harmful drinking is described as a pattern of drinking which already causes detriment to health, either physical or mental, as well as psychological and social harm, although alcohol dependence does not occur yet. In order to recognize harmful alcohol abuse, the described pattern of drinking should be maintained for at least a month or occur in a repeated way during a period of 12 months [2].

Various authors more and more often we encounter the term "occasional excessive drinking" which is held responsible for certain health or social harms. That means drinking at one time, although occasionally, large amounts of alcohol. There are many systems of classifying people drinking alcohol. Usually people who drink less than one time a year are considered teetotalers, occasional drinking means consuming alcohol at least once a month, light drinking is consumption of one glass of alcohol at least once a month, drinking three to four glasses of alcohol once a month means moderate drinking, excessive drinking is consumption of five gasses of alcohol almost every day. The maximum daily dose of alcohol which can be consumed by a healthy person without detriment to the body has not been established yet. It is estimated that for men this amount is approximately $40 \mathrm{~g}$ and for women approximately $20 \mathrm{~g}$. Daily consumption of the amount greater than $80 \mathrm{~g}$ in the case of men and $40 \mathrm{~g}$ in the case of women is considered to be excessive drinking. The majority of people, however, do not know precisely how much alcohol is contained in beverages they drink, and this is the main cause of excessive alcohol consumption. Such an established model of drinking can lead to psychological dependence, which consists in the need for frequent or constant drinking of alcoholic beverages in order

\footnotetext{
${ }^{1}$ Chair and Department of Public Health, Medical University of Lublin, Lublin, Poland

${ }^{2}$ Master of Pharmacy

${ }^{3}$ Master of Environmental Protection
} 
to repeat previous experience related to their consumption. The next stage is physical dependence which means a state of biological adaptation to alcohol without which the organism cannot function properly. Interrupting or limiting consumption of alcohol involves disturbances of bodily functions, named as abstinence (withdrawal syndrome) [2,3].

Young people's alcohol drinking young people impairs cognitive functions - concentration of attention, remembering, learning, development of emotional control, it also causes risky behavior mentioned above which may pose a threat to life and health, it disturbs the process of development and may eventually slow down growth and cause hormonal disturbances [2]. In whole Europe excessive alcohol consumption is responsible for L' of all sudden deaths among young people between the age of 15 and 29 . Women the same levels as men do men when it comes to risky and harmful drinking. It is worth noting here that alcohol acts in a different (more toxic) way upon the female body and that the risk of negative consequences of alcohol consumption by women is significantly higher. The risk increases together with an increase in the amount of consumed alcohol. It should be noted that women drinking in excess are more often than men who drink victims of accidents, injuries, physical abuse, rape and sexual harassment. In the case of women, in comparison to men, risky alcohol consumption may be a cause of cross addictions and mood disturbances, especially characterized by anxiety and depression $[4,5]$.

Alcohol accompanies young people in many situations, for example birthdays, social gatherings, after-exam parties, or during the students' days of culture. High-proof alcoholic beverages help solve problems, make friends and quickly improve the mood. Students drink to relax, feel good, alleviate stressful situations at home or university, get stimulation when they are tired, because alcohol helps them fall asleep, it tastes good, reduces boredom, quenches thirst, because this is the way their friends behave, they drink to gain a position among fellow students and to enjoy themselves $[1,6,7]$.

The research commissioned by PARPA (State Agency to Solve Problems of Alcohol) and conducted by the Institute of Psychology of Health among students of the Warsaw Medical University in 2004 shows that during the last two weeks before the study nearly $50 \%$ of students abused alcohol, $53 \%$ of women and $47 \%$ of men. At the same time $32 \%$ of men and $23 \%$ of women admitted that they got drunk during the last month [5]. In other Polish studies conducted among students of VI year of the Medical Faculty (143 people) it was found that $46 \%$ of students consumed alcohol in a risky way, nearly three times more men than women [8].

\section{AIM}

The aim of the study was an attempt to answer the question concerning influence of alcohol consumption on risky behavior among first and fourth year students of the Medical Faculty at the Medical University in Lublin during the academic year 2011/2012.

\section{First year male students}

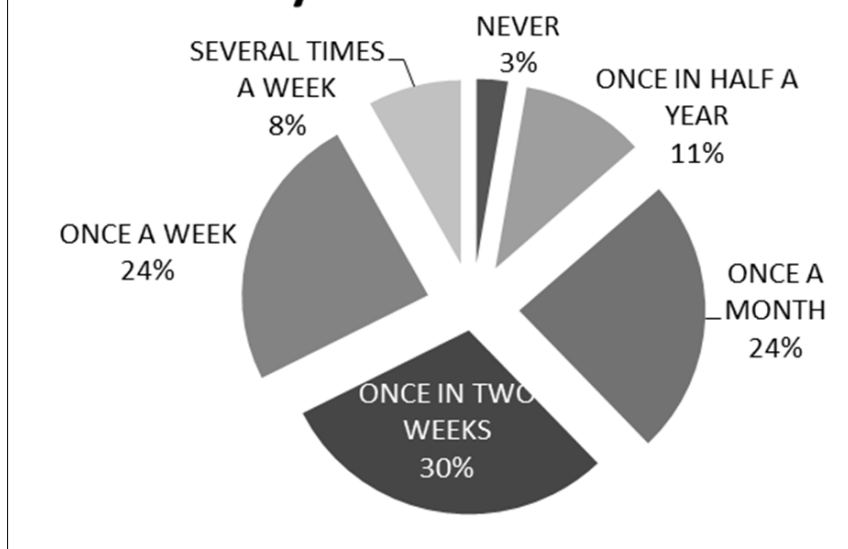

\section{Fourth year female students}

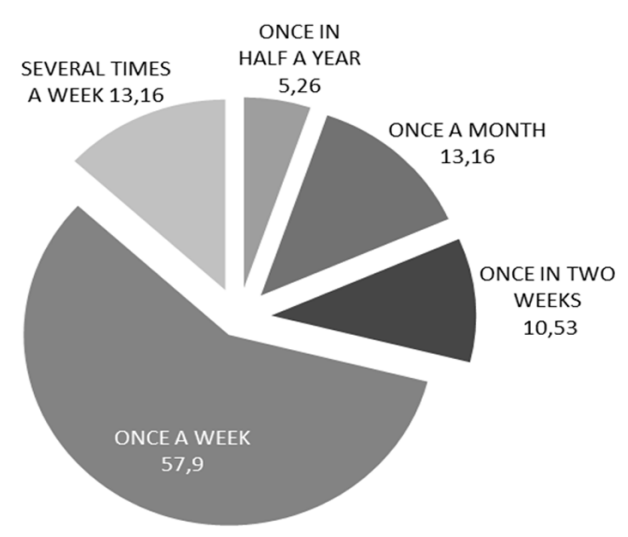

ONCE IN HALF
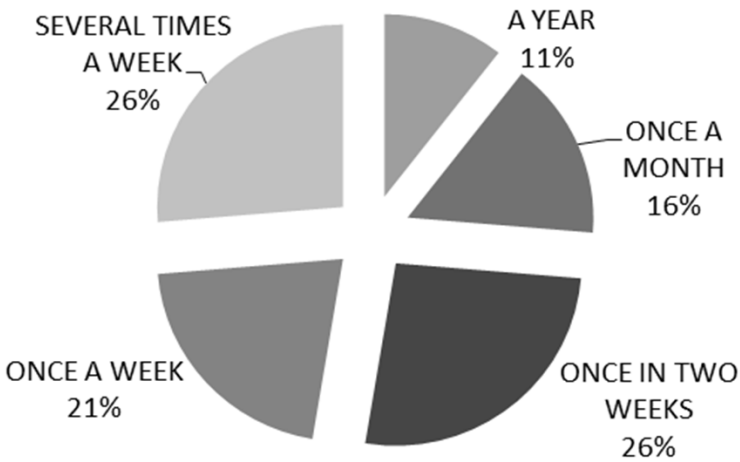

\section{Fourth year male students}

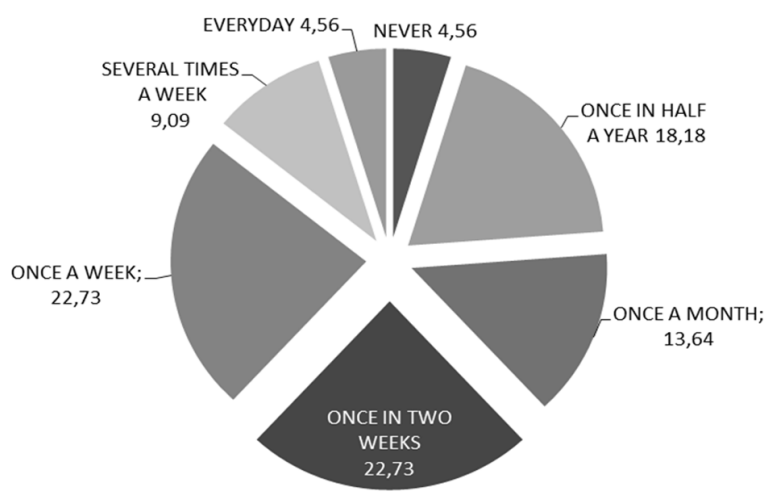




\section{MATERIAL AND METHODS}

The study looked at 120 students, 45 men and 75 women; 60 people from the first and 60 people from the fourth year of the Medical Faculty. The method of an author's original questionnaire, which was fully anonymous, was used. Answering 22 questions included in the questionnaire was voluntary, those completing the questionnaires could refuse to participate in the study at any time.

\section{RESULTS}

Drinking alcohol is a common phenomenon among the examined young people studying in Lublin. Only slightly above $1.50 \%$ (two persons) of the studied population declare full abstinence, so this attitude is extremely rare. One person answered that he uses alcohol every day. Forty-five percent of the respondents say that they consume alcohol once a week. That was admitted by $22.72 \%$ of men and $57.89 \%$ of women. The distribution of other answers is presented in the figure 1-4.

Intensity of drinking and frequency of intoxication spells is greater in female respondents than in men. It indicates the fact that differences between the sexes become less and less significant. Students admit that it has happened they got drunk to the point of losing consciousness. Such a situation has occurred more than once (2-3 times) to $15 \%$ of the fourth year respondents and $11.60 \%$ of the first year respondents.

In the studied group of the first year students the use of swear words after alcohol consumption increased by $10 \%$, alcohol did not affect frequency of using swear words among the fourth year students. The results are presented in the Table 1.

TABLE 1. Use of swear words after alcohol consumption.

\begin{tabular}{lcccc}
\hline \hline & \multicolumn{2}{c}{ FIRST YEAR } & \multicolumn{2}{c}{ FOURTH YEAR } \\
\hline & Yes (\%) & No (\%) & Yes (\%) & No (\%) \\
\hline $\begin{array}{l}\text { Use of swear words every day } \\
\begin{array}{l}\text { Use of swear words } \\
\text { after alcohol consumption }\end{array}\end{array}$ & 35 & 65 & 45 & 55 \\
\hline
\end{tabular}

It can be concluded on the basis of the conducted study that drinking alcohol is often accompanied by using other psychoactive substances. This is admitted by over $10 \%$ of the respondents. Drunken students become intoxicated with narcotic drugs and they smoke cigarettes. Three men and two women admit to having smoked marijuana under the influence of alcohol. One of the fourth year respondents intoxicated by alcohol took cocaine.

TABLE 2. Ingestion of psychoactive substances and smoking cigarettes after alcohol consumption.

\begin{tabular}{lcccc}
\hline \hline & \multicolumn{2}{c}{ FIRST YEAR } & \multicolumn{2}{c}{ FOURTH YEAR } \\
\cline { 2 - 5 } & Yes (\%) & No (\%) & Yes (\%) & No (\%) \\
\hline Psychoactive substances & 11.6 & 88.4 & 15 & 85 \\
Cigarettes* & 10 & 75 & 18.33 & 63.3 \\
\hline
\end{tabular}

* People not included in the table are tobacco addicts.
Negative consequences of drinking among young people usually include: driving under the influence of alcohol, risky sexual behavior, taking part in fights. Five percent of the respondents confirmed driving after consumption of alcohol. Thirty percent of the fourth year students and $25 \%$ of the first year respondents report that they were passengers when the driver was drunk. The consequences of such behavior include conflicts with the police $(12 \%)$ and breaking the law $(30 \%)$. Fourth year students intoxicated by alcohol more frequently decide to have sexual contacts. Such behavior is more common in men $(54.50 \%)$ than in women $(36.84 \%)$. Answers concerning effects of alcohol consumption are presented in the Figure 5.

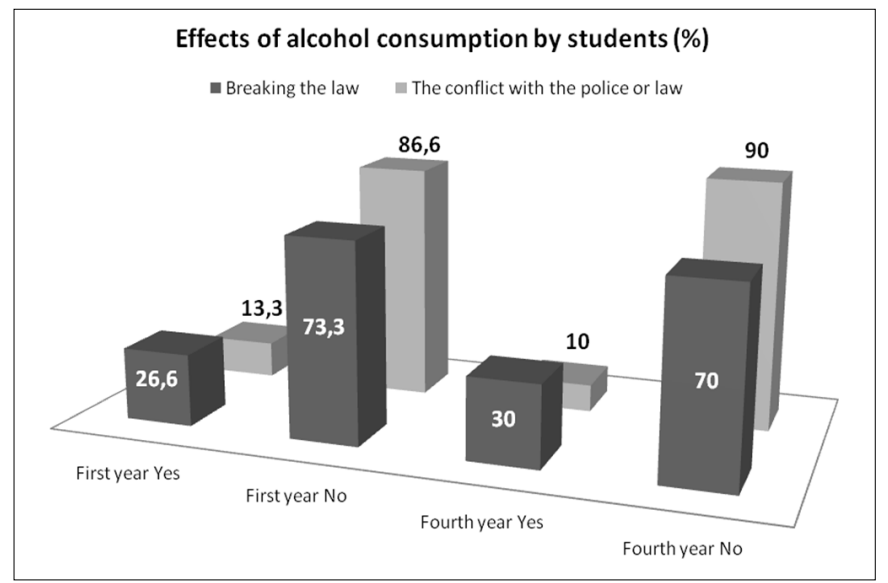

FIGURE 5. Negative effects of alcohol consumption.

The students who completed the questionnaires admit that having drunk alcohol, they neglect their duties, also those related to studying medicine. Younger students in particular choose parties much more often than studying, which leads to falling behind the rest of students.

Alcohol consumption also affects taking irrational decisions which may pose a threat to life and health, e.g. jumping from a roof. The fourth year students occasionally gamble, which may become a cause of financial and family problems in the future.

After consumption of high-proof alcoholic beverages older students become more aggressive than their younger peers. The phenomenon is more frequently observed in men $(22.71 \%)$ than in women $(10.52 \%)$. They tend to provoke other people from their surroundings. Three persons from the first year admit to autoaggression. Forty percent of the respondents lose control over their behavior, which can cause aggression towards others. One student admitted to beating other students.

Drinking alcohol carries the risk of numerous negative effects, also those concerning health. Five percent of the first year students admit that they have sought medical help after consuming alcohol. The most common symptom occurring on the following day is "hangover". It always occurs in over $16 \%$ of the respondents.

\section{DISCUSION}

Results discussed above confirm the increasingly common problem of risky behavior after consumption of alcohol by students of the Medical University. However reports in the literature of the subject still insufficient. Therefore it is necessary to make further attempts to study this phenomenon $[1,2,6,8]$. 
Presented data are especially interesting in the context of the respondents' future profession - they are going to be doctors. Comparing the profile of respondents can be said that they are not significantly different from the profile of students from other medical universities. This phenomenon is especially dangerous because of the fact that in the future, respondents would be expected to promote healthy lifestyle $[7,8]$.

The results of our research showed that the most common risk behaviors co-occur with each other. In addition, the behavior of one entails the other. For example, alcohol use is often accompanied by aggressive behavior, crime and early sexual activity. They may also be triggered in this way. Under the influence of alcohol, young people take a number of other risky behaviors. Impaired ability to control their own behavior causes crossing subsequent borders [6,7].

Other studies conducted among the students of the Medical University of Lublin show that not only medical students have problems with alcohol abuse. Conclusions from a study of similar group of respondents confirm the growing trend of the frequency of alcohol consumption. It is confirmed that the level of consumption is increasing with the passage of studies and mainly affects women (Figures 1 and 4). A similar trend concerns driving under the influence. The incidence of this phenomenon is comparable with other students $(5 \%$ of medical students and $7.95 \%$ of all surveyed students at medical school). Such risky behavior entails conflicts with the law and in case of compared studies also applies to about $12 \%$ of respondents ( $12.5 \%$ of men and $0.92 \%$ of women) [9].

\section{CONCLUSIONS}

There is a relationship between drinking alcohol, smoking cigarettes and taking narcotic drugs. We observed a high rate of alcohols among female students. Among negative consequences of drinking alcohol by young people the most often are: driving a car under the influence of alcohol, undertaking risky sexual behaviors, participation in scuffles. Several respondents admitted that they were passengers while the driver was intoxicated. Conflicts with police and a law-breaking were consequences of such actions. Students being in a state of intoxication more often decided on casual sexual contacts. Drinking alcohol might also result in irrational decisions which could endanger health and lives e.g.: jump from the roof. A few students of the fourth year were occasionally involved in gambling. Consequently it might cause familiar and financial problems in the future. A number of students admitted undergoing medical assistance after alcohol consumption. To summarize, alcohol overuse still brings a lot of negative effects, including those affecting health and changes in alcohol policy are necessary. There is a need for educating young people about the effects of drinking alcohol to take risky behaviors.

\section{REFERENCES}

1. Pietryka-Michałowska E, Wdowiak L, Dreher P. Zachowania zdrowotne studentów akademii medycznej. II. Analiza spożycia alkoholu, palenia papierosów, zażywania narkotyków, picia kawy. Zdr Publ. 2004;114(4):5326.

2. Fudała J. Jak pomagać osobom pijącym alkohol ryzykownie i szkodliwie. Warszawa: Wydawnictwo Edukacyjne Parpamedia; 2008.

3. Pużyński S. Leksykon psychiatrii. Warszawa: Państwowy Zakład Wydawnictw Lekarskich; 1993.

4. Kostowski W, Herman ZS. Warszawa: PZWL; 2010. p.642-3.

5. Woronowicz B. Alkoholizm jest chorobą. Warszawa: Państwowa Agencja Rozwiązywania Problemów Alkoholowych; 1998.

6. Gerstenkorn A, Suwała M. Picie alkoholu przez studentów medycyny. Zdr Publ. 2004;114(1):59-62.

7. Klimberg A, Marcinkowski JT, Przybylski J. Konsumpcja alkoholu i innych środków psychoaktywnych wśród studentów poszczególnych kierunków uniwersyteckich studiów medycznych. Probl Hig Epidemol. 2009,90(2):218-21.

8. Sidor K, Makara-Studzińska M. Profil studentów pijących ryzykownie w grupie studentów Uniwersytetu Medycznego w Lublinie. Hygeia Public Health. 2012;47(1):85-8.

9. Fałkowski A, Furtak-Niczyporuk M, Iwaniuk A, et al. Impact of prices on the prevalence of alcohol consumption among medical school students. Zdr Publ. 2013;123(4):298-300.

\section{Corresponding author}

Agata Słowińska

Katedra i Zakład Zdrowia Publicznego

ul. Chodźki 1, 20-093 Lublin

E-mail: zdrowie.publiczne@umlub.pl 